\title{
PERFORMANCE OF COPPER AZOLE TREATED SOFTWOODS EXPOSED TO MARINE BORERS
}

\author{
${\text { Hüseyin Sivrikaya }{ }^{1, \diamond}, \text { Hakan Çetin }{ }^{2}, \text { İbrahim Tümen }{ }^{1} \text {, Cengiz Temiz }{ }^{3}, \text { L.M.S. Borges }}^{4}$
}

\begin{abstract}
Wooden material has been used for shipbuilding and structural purposes in the marine environment since ancient times. Wood being used in the sea water can be damaged by marine wood boring organisms, which can turn marine wooden structures unserviceable with great economic cost. Using naturally durable species and preservative treated wood can increase the service life of wooden maritime structures and avoid or minimise the damages caused by marine borers. In this study, Scots pine (Pinus sylvestris), Black pine (Pinus nigra) and Turkish fir (Abies bornmülleriana) naturally grown and economically important wood species in Turkey were treated with copper-azole and evaluated in marine trials for 7 and 14 months in the Western Black Sea region. In this experiment, Teredo navalis was the only teredinid species identified. Copper-azole treated fir and Scots pine specimens suffered no attack, after 7 and 14 months exposure, except four panels which suffered minor damage. However, copper-azole treated Black pine panels were moderately damaged, and all of the control panels of the softwoods were strongly attacked. The average largest shell diameter was found to be $4,79 \mathrm{~mm}$ in Scots pine, while the longest pallets $(4,71 \mathrm{~mm})$ was found in Black pine.

All untreated test panels scored an average of 4 (heavily attacked) after a 14 month period. The cellulose ratio of Black pine decreased from $56 \%$ to $50 \%$, and the holo-cellulose ratio from $76 \%$ to $71 \%$. The treated samples showed resistance against marine borers although the copper $(\mathrm{cu})$ leaching was high during the 14 months exposure underwater.
\end{abstract}

Keywords: Copper azole, marine borer test, chemical analyses, Scots pine, Black pine, Turkish fir, Teredo navalis.

\section{INTRODUCTION}

Wood has been used as a traditional material for construction of marine structures, such as groynes and jetties (Crossman and Simm 2004), as well as yachts and other boats. This can be attributed to the specific properties of wood, for instance relatively low energy costs of production, high strength to weight ratio, ease of fabrication and repair and renewability. However, biodegradation of wood is particularly severe in maritime construction due to the activity of marine wood boring molluscs (teredinids) and crustaceans (limnoriids), in comparison to decay fungi, beetles and termites active

\footnotetext{
${ }^{1}$ Faculty of Forestry, Department of Industrial Forest Engineering, Bartın, Turkey.

${ }^{2}$ Bulent Ecevit University, Vocational High School, Çaycuma, Zonguldak.

${ }^{3}$ Science and Technology Research and Application Center, Bulent Ecevit University, Zonguldak, Turkey.

${ }^{4}$ Helmholtz-Zentrum Geesthacht, Centre for Material and Coastal Research, Max-Planck-Straße, Germany.

•Corresponding author: hsivrikaya@bartin.edu.tr

Received: 07.03.2015 Accepted: 24.02.2016
} 
above the waterline (Cragg 1996, Borges et al. 2009). To prevent borer attack, the wood is in some cases treated with biocides. Another approach is to use naturally durable wood species for marine construction. Heartwood of certain tropical timbers has sufficient natural durability due to the extractives or silica content to be useful in the marine environment (Fougerousse 1971, Southwell and Bultman 1971), particularly in areas with low borer hazard.

However, the utilization of durable hardwood species, particularly tropical hardwoods resistant to biodegradation, has led to tropical deforestation that continues to be a cause of concern, although there are many factors associated with this other than the use of timber in maritime structures The decline of naturally durable species gave rise to the treatment of softwoods by using preservatives to achieve satisfactory protection and longevity under service conditions, particularly for exterior applications (Hill 2006).

In earlier studies, conventional preservatives, such as creosote, chromated copper arsenate (CCA), ammoniacal copper arsenate (ACA), ammoniacal copper zinc arsenate (ACZA) as well as dual treatment (water-borne preservative followed by creosote) were used by vacuum pressure treatments to protect wood in marine conditions (Johnson 1986). However, it has been demonstrated, in long-term field trials, that CCA and creosote protect wood against teredinid borers, but not against crustacean borers (limnoriids) (Eaton 1989, Cookson and Barnacle 1987). However, the dual CCA and creosote treatment performed well (Cookson 1986).

Softwoods which were pressure treated with creosote to recommended retentions performed satisfactorily in temperate waters, whereas treatments with less than $320 \mathrm{~kg} / \mathrm{m}^{3}$ were found susceptible to attack in tropical waters. On the other hand, copper-containing preservatives perform well as long as sapwood is fully penetrated and dry salt retention is over $32 \mathrm{~kg} / \mathrm{m}^{3}$ in temperate waters, and $48 \mathrm{~kg} /$ $\mathrm{m}^{3}$ in tropical sites (Eaton 1993). Copper chromate (CC) performed as well or better than CCA over 25 years in marine trials near both Sydney and Perth (Barnacle and Cookson 1995). Good performance of copper chromate was also shown by Preston and Chittenden (1980) after 2,5 years in New Zealand waters, and after 16 years in Sweden (Bergman and Lundberg 1990).

CCA was the most used wood preservative in the world in many structures including residential decks, public playgrounds, and building materials as well as in aquatic environments (Hingston et al. 2001, Tascioglu et al. 2003, Choi et al. 2012). However, growing environmental concerns have led to legislation that resulted in restriction or banning of its use due to the release of arsenic and chromium into the environment. Despite the banning on arsenic and chromium, copper is still allowed to be used in all classes as well as in the marine environment (class 5) due to its efficacy (EN 335, 2006). However, chromium was replaced with amines particularly ethanolamine, but the fixation of copperethanolamine is not as efficient as the copper-chromium (Humar et al. 2001).

In this study, we used copper-azole, water borne preservative, against marine borers in the Black Sea, as an alternative to CCA, since it is free of arsenic. Moreover copper-azole has advantage over $\mathrm{CC}$ compounds due to the absence of chromium. Therefore, the main aim of this study was to assess the performance of copper-azole, treated softwoods (Scots pine (Pinus sylvestris), Black pine (Pinus nigra) and Turkish fir (Abies bornmülleriana) against marine borers for use in the Black Sea area. Furthermore, in this study we present the copper analysis by EDXRF and chemical characterization of the degraded wood, which was not done in our previous studies (Sivrikaya et al. 2009, Sivrikaya et al. 2012, Sen et al. 2010). 


\section{MATERIALS AND METHODS}

\section{Wood specimens}

The panels were prepared from three wood species, grown in the West Black Sea region, Scots pine (Pinus sylvestris L.) sapwood, Turkish fir (Abies bornmülleriana Mattf.) sapwood and Black pine (Pinus nigra Arn. subsp pallasiana var. pallasiana) heartwood. The use of heartwood in the case of Black pine was due to the fact that in this wood species the proportion of heartwood is larger than that of sapwood. The samples were free of knots and showed no visible evidence of infection by mold, stain, or wood-decaying fungi.

Wood panels were cut with the following dimensions 25 x 75 x $200 \mathrm{~mm}$, according to the European standard EN 275 (1992).

The treatment of panels was carried out in an industrial plant by traditional vacuum pressure method based on the principles of full-cell process at the concentration 2,36 \% of copper-azole. The retention of the treated wood specimens was determined based on the formula given below;

$$
\text { Retention }=\frac{G \times C}{100 \times V} \mathrm{~kg} / \mathrm{m}^{3}
$$

Where:

G: uptake of the preservative solution $(\mathrm{kg})$

$\mathrm{C}$ : concentration of the solution (\%)

$\mathrm{V}$ : volume of the sample $\left(\mathrm{m}^{3}\right)$

\section{Marine exposure}

For the marine trial, 8 untreated and treated replicate samples of each wood species were used in order to determine the severity of attack by wood boring organisms. The numbers of wooden panels were in total 96 including untreated and treated panels of the three wood species for 7 and 14 months exposure. The panels were suspended vertically during low tide at a depth of $6 \mathrm{~m}$ below water surface, with the larger dimension of the panels orientated horizontally.

Untreated and treated samples were deployed in Amasra Bay $\left(41^{\circ} 45^{\prime} \mathrm{N}, 32^{\circ} 23^{\prime} \mathrm{E}\right)$, in the Western Black Sea region from June 2007 to August 2008, temperature of the sea water was recorded for each month. 48 samples stayed under water for 7 months and 48 for 14 months.

After each period of exposure, 48 panels were taken from the water and then split open in order to reveal the extent of interior damage and to extract the wood boring organisms. The severity of attack was visually assessed, and each panel was rated according to the categories defined in EN 275 (1992). In this rating system, the samples having no attack were rated zero (0), whereas 4 was attributed to the heavy degraded samples. In some cases whole animals were removed from the panels. However, in other cases the soft body parts were decomposed, only pallets and shells were collected. Pallets and shells were preserved in absolute ethanol, and then their lengths and diameters were measured using a digital calliper. Teredinids were identified using the keys in Turner (1971) and descriptions in Turner (1966). After the animals were extracted, shells and pallets were collected and all calcareous residues were removed. The percent of mass loss for only untreated panels attacked by shipworm was calculated based on the difference between air-dried weights before and after the marine trial. 


\section{Chemical analysis}

Chemical analysis of untreated wooden panels exposed (during 7 and 14 months) and unexposed to marine trials was performed to determine alcohol, hot water and cold water solubility. The holocellulose, a-cellulose and lignin ratio were also determined in the untreated samples, including unexposed and exposed to the marine trial (for 7 and 14 months). For this purpose, the wood specimens were first chipped and ground in the mill and sieved to 60 mesh size, then three replicates of those were used for the chemical analysis.

Alcohol solubility was determined according to TAPPI T204 cm-97, hot water and cold water solubility TAPPI T207 cm-99 method. Determination of the holocellulose content was performed according to the chloride method developed by Wise and John (1952). The a-cellulose content was determined based on the insoluble matter resulted from the holocellulose (Han and Rowell, 1997). For the analysis of the lignin ratio we used the TAPPI T211 method.

\section{Energy dispersive X-ray fluorescence (EDXRF) analysis}

To determine the $\mathrm{Cu}$ quantity, the round small specimens in $32 \mathrm{~mm}$ diameter were cut from the treated control and treated exposed wood panels. Two specimens for each group were left in an oven under the temperature of $60^{\circ} \mathrm{C}$ for one day, then air blast at $1 \mathrm{mbar}$ was applied on the surface of the specimens to clean surface from the dust particles. The measurement was performed by Energy dispersive X-ray fluorescence (EDXRF) Epsilon 5 model instrument by scanning the surface with $\mathrm{X}$-ray for $25 \mathrm{~min}$. on each specimen.

\section{RESULTS AND DISCUSSION}

\section{Assessment of preservative retention in test panels}

Average values of oven-dry densities and copper-azole retentions in the wooden panels used in the 7 and 14 months marine trials are shown in Table 1.

Table 1. Mean oven-dry densities and preservative retentions of the samples \pm SD.

\begin{tabular}{|c|c|c|c|c|c|c|}
\hline $\begin{array}{c}\text { Wood } \\
\text { species }\end{array}$ & Scientific name & Type & $\begin{array}{c}\text { Oven dry } \\
\text { density of } \\
\text { unexposed } \\
\text { samples }\left(\mathrm{kg} / \mathrm{m}^{3}\right)\end{array}$ & $\begin{array}{c}\text { Retention-7 } \\
\text { months exposure } \\
\left(\mathrm{kg} / \mathrm{m}^{3}\right)\end{array}$ & $\begin{array}{c}\text { Retention-14 } \\
\text { months exposure } \\
\left(\mathrm{kg} / \mathrm{m}^{3}\right)\end{array}$ & $\begin{array}{c}\text { Homogenous } \\
\text { subsets for } \\
\text { retention values }\end{array}$ \\
\hline Scots pine & Pinus sylvestris & Sapwood & $520 \pm 30$ & $9,62 \pm 0,69$ & $9,85 \pm 0,59$ & (b) \\
\hline Black pine & Pinus nigra & Heartwood & $470 \pm 30$ & $8,59 \pm 0,91$ & $8,64 \pm 0,72$ & (a) \\
\hline Turkish fir & $\begin{array}{c}\text { Abies } \\
\text { bornmülleriana }\end{array}$ & Sapwood & $420 \pm 20$ & $10,81 \pm 1,15$ & $10,49 \pm 0,85$ & (c) \\
\hline
\end{tabular}

The level of retention was found to be the highest in fir, followed by Scots pine and Black pine. The difference was significant among each species at the $95 \%$ confidence $(\alpha=0,05)$ level based on ANOVA and Tukey test. The density of the fir sapwood was lower than that of Scots pine, but a high retention was obtained in this species as well. There was no linear relationship between the density of the sapwood of both species and the retention values. However, the retention value in the Black pine samples prepared from heartwood was slightly lower than that in the sapwood of Black pine and Scots pine.

\section{Evaluation of the marine trial}

The water temperature during the marine trial ranged from $6,8^{\circ} \mathrm{C}$ in February 2008 to $24,7^{\circ} \mathrm{C}$ in August of 2007. The average temperature in the test site was $16,5^{\circ} \mathrm{C}$; while the average salinity of the 
sea water was 18 Practical Salinity Unit (PSU).

Teredo navalis was found to be the only species present in test panels exposed in the sea. The activity of T. navalis was also reported to be high in the test site in earlier experiments (DKK 1997, Sivrikaya et al. 2012). Moreover, the activity of this species is reported to be high in different sites in Europe (Westin et al. 2006, Paalvast and Van der Velde 2011, Lopes et al. 2014, Borges 2014).

The number of attacked panels and severity of the degradation are given in Figure 1, and the pictures of the test panels in Figure 2.

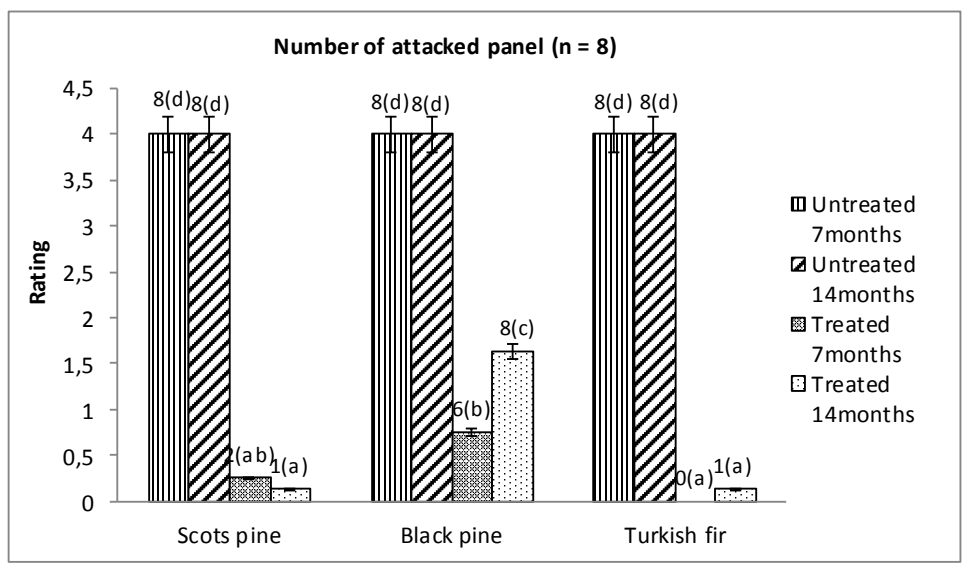

Figure 1. Mean severity of attack in samples by marine wood borers (rating) $\pm \mathrm{SD}$, the numbers indicate the attacked panels of Scots pine (Pinus sylvestris), Black pine (Pinus nigra) and Turkish fir (Abies bornmülleriana)

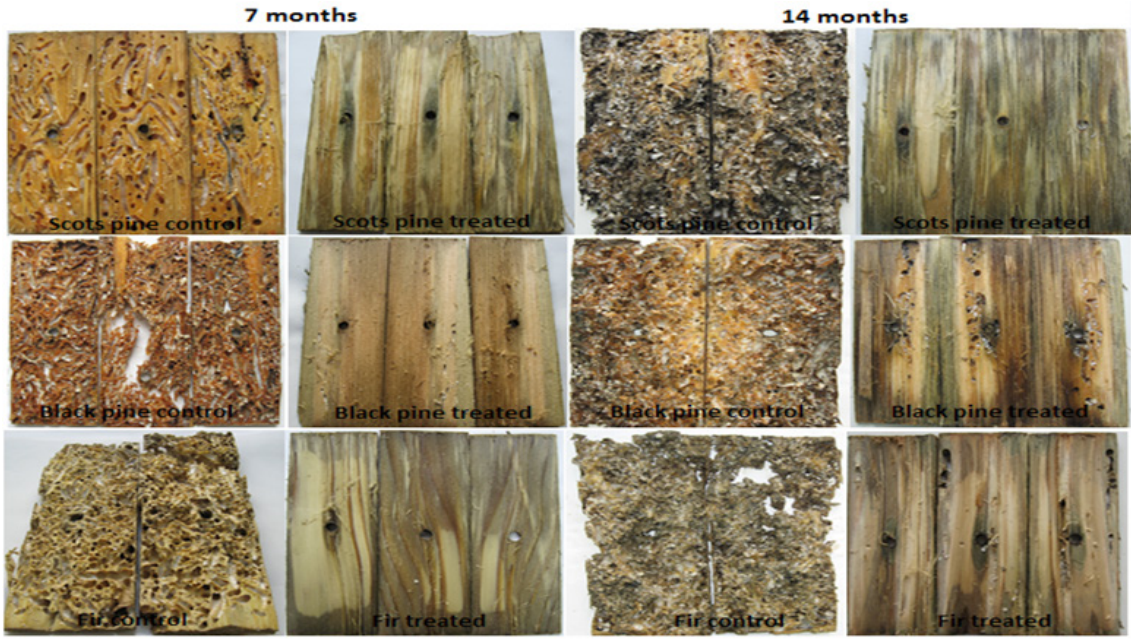

Figure 2. Seven and 14 months exposed panels of Scots pine (Pinus sylvestris), Black pine (Pinus nigra) and Turkish fir (Abies bornmülleriana) (control and treated).

All untreated samples were heavily attacked by Teredo navalis after the periods of 7 and 14 months. The attack was severe in all untreated panels which were graded 4 because of the numerous holes, whereas treated panels ranged between 0 and 1 as a result of slight attack (Figure 1). The samples of Black pine heartwood also showed poor resistance against $T$. navalis. These results indicate that the native wood species from Europe must be protected with biocides in order to provide sufficient 
resistance against marine borers. This was confirmed by the experiment performed in the Adriatic Sea where untreated specimens of Scots pine sapwood as well as naturally durable heartwood of European oak, European larch and sweet chestnut were completely degraded in 10 months (Humar and Lesar 2013).

In this study, Figure 1 suggests that wood treated with Copper azole shows great resistance against shipworms. Scots pine treated with copper-azole performed well against Teredo navalis, whereas treated samples of Black pine and fir panels were slightly attacked, although they had similar retention values, in 14 months exposure. For treated samples, two panels of Scots pine and six of Black pine were subjected to boring attack, while fir was free of attack during 7 months. After14 months treated panels; one of Scots pine, all samples of Black pine and one panel of fir were affected by boring organisms. This may be caused by the leaching of the copper from these panels underwater during the exposure period. Therefore, higher retention levels of copper-azole may confer higher protection against marine wood borers. In further studies this limitation should be addressed and marine trials should be held for a longer period, to provide better insights into the long-term protection conferred by copper azole treatments.

The comments made on Figure 1 regarding the severity of degradation caused by Teredo navalis are in accordance with the visual examination as shown in Figure 2.

Naturally durable species and several copper based wood preservatives were discussed in some publications, which involved marine trials in different test sites.

Şen et al. $(2009,2010)$ reported the performance of 33 wood species, both tropical and nontropical, in 6 different sites in Turkey. Moderate attack appeared in non-tropical and trace attack in tropical wood species, in the site close to our test site in the West Black Sea region, where the borers Teredo navalis and Lyrodus pedicellatus were identified. Furthermore, heavy destruction was shown in the East Black Sea region, where T. navalis, L. pedicellatus and Nototeredo norvagica recruited to test panels. Besides, the wood samples treated with CCA and CCB (copper, chromium, boron) were not damaged by the borers at six stations in one year.

T. navalis was also identified in Swedish west coast and its activity was found to be very high on untreated Scots pine samples, which were destroyed in one year (Westin et al. 2006). In another study regarding copper based preservative, Indonesian wood species treated with chromated copper boron (CCB) performed well against marine borers. Specimens treated with CCB by the full cell treatment were able to prevent marine borer attack in contrast to the untreated wood samples which were susceptible to the family of Teredinidae, Pholadidae and Sphaeromatidae except two wood species, lara (Metrosideros petiolata) and kandole (Diploknema oligomera) (Muslich 2006).

A recent study assessed the performance of copper-ethanolamine-based wood preservative after periods of 10, 18 and 32 months in the northern Adriatic Sea, in comparison to the untreated and naturally durable heartwood which were strongly destroyed in 10 months. However, samples with the highest concentration of copper showed almost no attack, and the samples with the lowest concentration were only slightly degraded (Humar and Lesar 2013). 


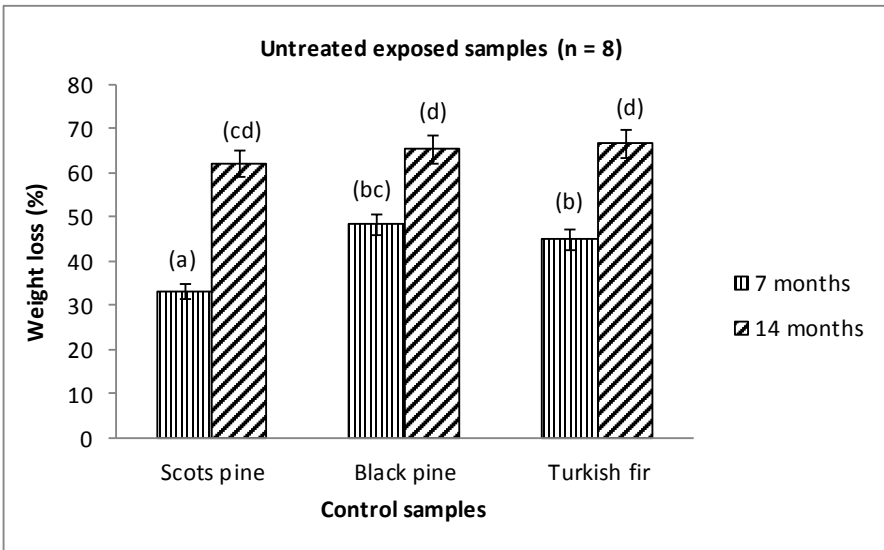

Figure 3. Weight loss of untreated Scots pine (Pinus sylvestris), Black pine (Pinus nigra) and Turkish fir (Abies bornmülleriana) panels for 7 and 14 months \pm SD.

The weight loss, given in Figure 3, was calculated for the untreated panels destroyed by shipworms in this experiment, since there was almost no degradation in treated panels. Figure 3, indicates that weight loss was lower in Scots pine than others after 7 months; however, it was similar in all species left under water as long as 14 months. In addition, there was no significant difference to the mass loss among the wood species after 14 months. Therefore, it can be concluded that these softwoods can not be used without protection in marine conditions.

The retention, rates of attack and weight loss of the wood samples were statistically examined by analysis of variance (ANOVA), followed by the Tukey test. The homogeneous groups are displayed in Table 1, Figures 1 and 3.

There was a statistically significant difference between wood species in relation to retention, weight loss of untreated wood species, exposure period, and the rates of attack in the controls and treated woods.

Wood species differed from each other with regard to retention values. However, the weight loss was similar for Black pine and fir control samples, but significant differences were found between control and treated samples in relation to the rates of wood boring attack.

The data regarding shells and pallets which were collected from the panels are given in Table 2.

Table 2. Mean shell diameter and pallet length to Teredo navalis found in Scots pine (Pinus sylvestris), Black pine (Pinus nigra) and Turkish fir (Abies bornmülleriana) panels $\pm \mathrm{SD}$.

\begin{tabular}{|c|c|c|c|c|c|c|c|}
\hline & & 7 & Months & 7 & Months & 14 & Months \\
\hline $\begin{array}{l}\text { Wood } \\
\text { species }\end{array}$ & Treatment & $\begin{array}{c}\text { Total } \\
\text { number }\end{array}$ & $\begin{array}{c}\text { Shell* } \\
(\mathrm{mm})\end{array}$ & $\begin{array}{c}\text { Total } \\
\text { number }\end{array}$ & $\begin{array}{l}\text { Pallet } \\
(\mathrm{mm})\end{array}$ & $\begin{array}{c}\text { Total } \\
\text { number }\end{array}$ & $\begin{array}{l}\text { Pallet } \\
(\mathrm{mm})\end{array}$ \\
\hline $\begin{array}{l}\text { Scots } \\
\text { pine }\end{array}$ & $\begin{array}{c}\text { Untreated } \\
\text { treated }\end{array}$ & $\begin{array}{c}37 \\
1 \\
\end{array}$ & $\begin{array}{c}4,79 \pm 0,97 \\
2,15 \\
\end{array}$ & $\begin{array}{c}94 \\
2 \\
\end{array}$ & $\begin{array}{c}4,35 \pm 1,44(\mathrm{ab}) \\
1,83 \pm 0 \\
\end{array}$ & $\begin{array}{c}195 \\
2\end{array}$ & $\begin{array}{c}4,63 \pm 1,17(b c) \\
4,31 \pm 0 \\
\end{array}$ \\
\hline $\begin{array}{l}\text { Black } \\
\text { pine }\end{array}$ & $\begin{array}{c}\text { Untreated } \\
\text { treated }\end{array}$ & $\begin{array}{c}17 \\
-\end{array}$ & $\begin{array}{c}4,10 \pm 0,83 \\
- \\
\end{array}$ & $\begin{array}{c}121 \\
-\end{array}$ & $\begin{array}{c}4,71 \pm 1,05(\mathrm{c}) \\
-\end{array}$ & $\begin{array}{c}178 \\
8\end{array}$ & $\begin{array}{c}4,51 \pm 0,89(\mathrm{abc}) \\
3,78 \pm 0,46\end{array}$ \\
\hline $\begin{array}{l}\text { Turkish } \\
\text { fir }\end{array}$ & $\begin{array}{c}\text { Untreated } \\
\text { treated }\end{array}$ & $\begin{array}{c}38 \\
-\end{array}$ & $\begin{array}{c}4,41 \pm 1,08 \\
-\end{array}$ & $\begin{array}{c}117 \\
-\end{array}$ & $\begin{array}{c}4,58 \pm 1,17(b c) \\
-\end{array}$ & $\begin{array}{c}156 \\
2\end{array}$ & $\begin{array}{c}4,26 \pm 0,97(\mathrm{a}) \\
3,78 \pm 0\end{array}$ \\
\hline
\end{tabular}


In the test panels, a great number of shells were collected from the untreated samples, as opposed to treated ones which showed high resistance against shipworms, during the period tested. Nevertheless, no whole shells were found in the panels exposed during 14 months. The number of collected shells as well as their diameter was lower in Black pine compared to Scots pine and fir as shown in Table 2.

A wide range of pallets was extracted from all panels, but in the treated samples much fewer pallets were found. Statistical difference in pallet length in untreated woods is shown in Table 2 as homogeneous groups. The number of pallets was much higher in untreated panels exposed for 14 months than those exposed for 7 months. The average diameter of the shells was the biggest in Black pine in samples exposed for 7 months and the smallest in fir in the samples exposed for 14 months.

The maximum diameter of shells was measured in untreated Scots pine samples. However, the difference in shell diameter was not found significant in terms of the wood species according to ANOVA $(\mathrm{p}>0,05)$. Although no significant difference was found, the diameter of the shells reflects the size of the organism, which is related to their growth. Thus it seems that organisms are able to grow more easily in untreated Scots pine than in other untreated or treated woods. This was to be expected as Scots pine has been used in standard methods as a comparator for the performance of other wood species in marine trials (EN275 1992).

\section{Chemical analysis}

Chemical analysis results such as solubility, polysaccharides and lignin for untreated-unexposed and untreated- exposed samples are shown in Tables 3 and 4.

Table 3. Solubility values of the untreated samples of Scots pine (Pinus sylvestris), Black pine (Pinus nigra) and Turkish fir (Abies bornmülleriana).

\begin{tabular}{|l|l|l|l|l|}
\hline $\begin{array}{c}\text { Wood } \\
\text { species }\end{array}$ & \multicolumn{1}{|c|}{ Time } & \multicolumn{1}{|c|}{ Alcohol sol. (\%) } & Hot water sol. (\%) & Cold water sol. (\%) \\
\hline \multirow{3}{*}{ Scots pine } & Unexposed & $4,90 \pm 0,09(\mathrm{~d})$ & $3,22 \pm 0,04(\mathrm{a})$ & $2,19 \pm 0,06(\mathrm{a})$ \\
& 7 months & $3,89 \pm 0,2(\mathrm{~b})$ & $3,94 \pm 0,02(\mathrm{bc})$ & $2,59 \pm 0,34(\mathrm{ab})$ \\
& 14 months & $3,73 \pm 0,34(\mathrm{~b})$ & $4,05 \pm 0,25(\mathrm{bc})$ & $2,80 \pm 0,24(\mathrm{ab})$ \\
\hline \multirow{3}{*}{ Black pine } & Unexposed & $5,59 \pm 0,09(\mathrm{e})$ & $3,34 \pm 0,19(\mathrm{a})$ & $2,29 \pm 0,35(\mathrm{ab})$ \\
& 7 months & $4,67 \pm 0,3(\mathrm{~cd})$ & $3,67 \pm 0,12(\mathrm{ab})$ & $2,78 \pm 0,15(\mathrm{ab})$ \\
& 14 months & $4,12 \pm 0,23(\mathrm{bc})$ & $3,92 \pm 0,15(\mathrm{bc})$ & $2,87 \pm 0,15(\mathrm{bc})$ \\
\hline \multirow{3}{*}{ Turkish fir } & Unexposed & $2,68 \pm 0,15(\mathrm{a})$ & $3,60 \pm 0,22(\mathrm{ab})$ & $2,33 \pm 0,28(\mathrm{ab})$ \\
& 7 months & $2,41 \pm 0,32(\mathrm{a})$ & $3,89 \pm 0,16(\mathrm{bc})$ & $2,61 \pm 0,17(\mathrm{ab})$ \\
& 14 months & $2,39 \pm 0,12(\mathrm{a})$ & $4,19 \pm 0,17(\mathrm{c})$ & $3,47 \pm 0,18(\mathrm{c})$ \\
\hline
\end{tabular}

Table 4. Polysaccharides and lignin content of the untreated samples of Scots pine (Pinus sylvestris), Black pine (Pinus nigra) and Turkish fir (Abies bornmülleriana).

\begin{tabular}{|l|l|l|l|l|}
\hline $\begin{array}{c}\text { Wood } \\
\text { species }\end{array}$ & Time & Holocellulose (\%) & Alpha cellulose (\%) & Lignin (\%) \\
\hline \multirow{3}{*}{ Scots pine } & Unexposed & $75,35 \pm 1,35(\mathrm{bc})$ & $53,14 \pm 0,89(\mathrm{abc})$ & $25,34 \pm 0,08(\mathrm{~b})$ \\
& 7 months & $73,54 \pm 0,74(\mathrm{ab})$ & $51,86 \pm 0,44(\mathrm{ab})$ & $25,30 \pm 0,12(\mathrm{ab})$ \\
& 14 months & $71,82 \pm 0,7(\mathrm{a})$ & $51,18 \pm 0,3(\mathrm{ab})$ & $24,61 \pm 0,29(\mathrm{a})$ \\
\hline \multirow{3}{*}{ Black pine } & Unexposed & $76,27 \pm 0,92(\mathrm{bc})$ & $56,87 \pm 1,9(\mathrm{~d})$ & $26,79 \pm 0,28(\mathrm{c})$ \\
& 7 months & $71,58 \pm 0,82(\mathrm{a})$ & $50,82 \pm 0,61(\mathrm{a})$ & $26,58 \pm 0,06(\mathrm{c})$ \\
& 14 months & $71,58 \pm 2,07(\mathrm{a})$ & $50,96 \pm 1,33(\mathrm{a})$ & $25,57 \pm 0,34(\mathrm{~b})$ \\
\hline \multirow{3}{*}{ Turkish fir } & Unexposed & $79,86 \pm 0,68(\mathrm{~d})$ & $55,61 \pm 0,89(\mathrm{~cd})$ & $29,50 \pm 0,31(\mathrm{e})$ \\
& 7 months & $77,01 \pm 0,17(\mathrm{~cd})$ & $55,30 \pm 0,52(\mathrm{~cd})$ & $28,83 \pm 0,16(\mathrm{e})$ \\
& 14 months & $76,30 \pm 0,33(\mathrm{bc})$ & $53,94 \pm 0,83(\mathrm{bc})$ & $27,98 \pm 0,37(\mathrm{~d})$ \\
\hline
\end{tabular}


The difference among wood species in terms of solubility was found significant at $95 \%$ confidence level $(p<0,05)$. Table 3 , indicates that alcohol solubility gradually decreased with the increasing of exposure time, whereas hot and cold water solubility increased.

The relation between the chemical content of the wood species and the exposure periods were significant as shown in Table 4. Holocellulose, alpha cellulose and lignin content of the samples slightly decreased as long as the panels left were underwater. Cellulose ratio of Black pine decreased from 56 $\%$ to $50 \%$ and the holo-cellulose ratio decreased from $76 \%$ to $71 \%$ at the end of the marine trial. The other results regarding chemical constituents were found similar for the two-periods of exposure. Little differences in the chemical constituents of wood may be attributed to various factor; boring organisms or other microorganisms, environmental factors and gravimetric analysis.

There is little information on the chemical composition of wood deteriorated by marine borers. Archeological and modern oak wood were exposed to shipworm attack in the southern part of Kattegat, Denmark by Eriksen et al. (2015). For chemical analysis of the wood components, klason lignin and carbohydrates were determined by TAPPI methods in comparison to modern oak wood. Higher amount of klason lignin was found in archeological sapwood when compared to the modern oak wood since the carbohydrates was degraded in sapwood. Preserved lignin content was unnaturally high, but that was attributed to the gravimetric nature of the analysis.

However, research interest on the lignocellulosic digestion by microorganisms and marine wood borers has been increasing in recent years because of the interest on their metabolism system and biofuel production from biomass. According to King et al. (2010) limnoriids produce their own enzymes for lignocellulose digestion that makes these organisms unusual when compared to teredinids, which breakdown the lignocelluse with symbionts living in their gut in a similar manner as for termites. Distel (2003), reported that the bacterial endosymbionts in Teredinidae produce cellulolytic enzymes that play an important role in the digestion of wood.

$\mathrm{Cu}$ contents of the copper-azole treated samples are shown in Figure 4, for control (unexposed), 7 months and 14 months marine exposure respectively.

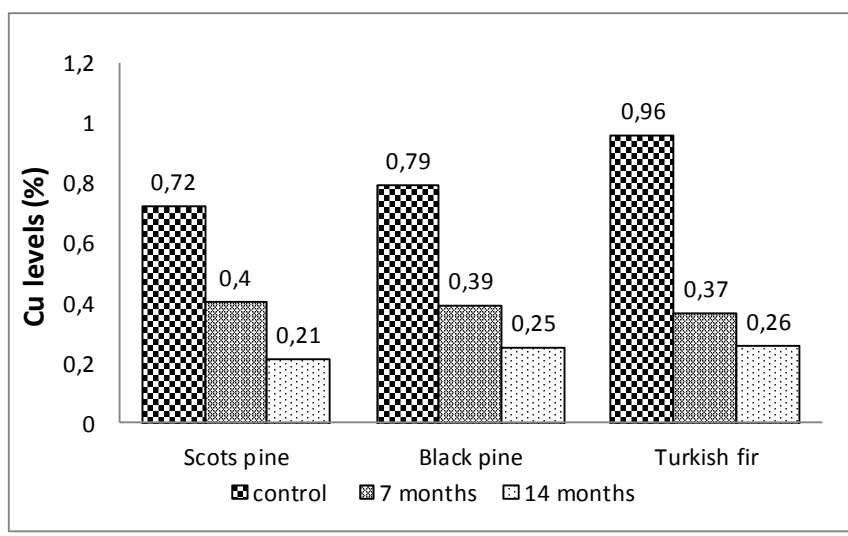

Figure 4. Mean $\mathrm{Cu}$ levels (\%) of the copper azole treated samples (control and exposed) for Scots pine (Pinus sylvestris), Black pine (Pinus nigra) and Turkish fir (Abies bornmülleriana)

Figure 4 indicates that $\mathrm{Cu}$ levels between control and exposed samples for 7 months differed higher in fir than Scots pine and Black pine. This also reveals the higher leaching of $\mathrm{Cu}$ from the samples during the 7 months exposure. It seems that $\mathrm{Cu}$ leaching continued from the samples underwater after 7 months. $\mathrm{Cu}$ loss ranged from higher to lower as follow; Scots pine, Black pine and fir between the samples exposed for 7 and 14 months. Some differences in $\mathrm{Cu}$ levels between the wood species might be attributed to the retention of the samples. It can also be said that the treated samples showed resistance against marine borers as shown in Figure 1 and Figure 2, despite the high $\mathrm{Cu}$ leaching.

The $\mathrm{Cu}$ loss was monitored in pine exposed in a coastal site within the first 12 weeks of a 72-week leaching trial (Hayes et al. 1994). Indeed, in several studies the leaching of $\mathrm{Cu}, \mathrm{Cr}$ and $\mathrm{As}$ components of CCA were investigated because this was the most effective and used preservative in the world at 
that time. In these studies, leaching of $\mathrm{Cu}$ was reported to be the highest in comparison to the other constituents (Breslin and Adler-Ivanbrook 1998, Weis et al. 1991, Baldwin et al. 1996, Merkle et al. 1993, Putt 1993).

\section{CONCLUSIONS}

This study once more confirmed that the marine-wood-borer Teredo navalis is the most widespread teredinid species in the test site (Amasra). Untreated Black pine showed poor resistance against marine borer attack, although it was composed of heartwood. Copper-azole treated wood showed a good performance against marine borer attack in the Black Sea, and its use as a treatment for softwoods might be a promising approach in marine conditions such as in warm waters.

We suggest the use of copper-azole in the Black Sea as well as in other European areas with similar characteristics with regard to marine borer diversity, temperature and salinity. However, further studies on the performance of copper-azole are needed both in cold and warmer waters in order to assess its performance in different abiotic and biotic conditions for longer periods.

In addition, comprehensive research should be made by advanced analytical techniques in the evaluation of chemical components of attacked wood by marine borers.

\section{ACKNOWLEDGMENTS}

This work was supported by the Scientific and Technological Research Council of Turkey (TUBİTAK), Project No: 1070647.

\section{REFERENCES}

Barnacle, J. E.; Cookson, L. J. 1995. Treated eucalypt and pine sapwood after 25 years in the sea. Part II. Major effect of wood type on the efficacy of some waterborne preservatives. J Inst Wood Sci 13: 543-558.

Bergman, Ö.; Lundberg, C. 1990. Water-borne wood preservatives against marine borers. Results from NWPC marine trials started in 1972 and 1976. Document No. IRG/WP/4162. International Research Group on Wood Preservation.

Baldwin, W.J.; Pasek, E.A.; Osborne, P.D. 1996. Sediment toxicity study of CCA-C treated marine piles. Forest Products Journal 46: 42-50.

Borges, L.M.S. 2014. Biodeterioration of wood exposed in the marine environment: evaluation of the hazard posed by marine wood borers in fifteen European sites. International Biodeterioration and Biodegradation 96: 97-104.

Borges, L.M.S.; Cragg, S.M.; Busch, S. 2009. A laboratory assay for measuring feeding and mortality of the marine wood borer Limnoria under forced feeding conditions: A basis for a standard test method. International Biodeterioration and Biodegradaion 63: 289-296.

Breslin, V.T.; Adler-Ivanbrook, L. 1998. Release of copper, chromium and arsenic from CCA-C treated lumber in estuaries. Estuarine Coastal and Shelf Science 46: 111-125.

CEN. European Committee for Standardization 2006: Durability of wood and wood-based products - Definition of use classes. EN 335.

Choi, Y.S.; Kim, J.J.; Min-Ji Kim, M.J.; Imamura, Y.; Yoshimura, T.; Kim, G.H. 2012. Fungal biodegradation of CCA-treated wood and removal of its metal components. Chemosphere 88: 725-729.

Cookson, L.J. 1986. Marine borers and timber piling options. Research Review CSIRO, Australia.

Cookson, L.J.; Barnacle, J.E. 1987. The performance in Australia after ten years in the sea of single and double preservative treated timber specimens. Mat u Org 22: 139-160. 
Cragg, S.M. 1996. Timber in the marine environment. Timber Trades Journal 376: 26-28.

Crossman, M.; Simm, J. 2004. Manual on the use of timber in coastal and river engineering. Thomas Telford Publishing, London.

Distel, D.L. 2003. The biology of marine wood boring bivalves and their bacterial endosymbionts. In: Goodell, B.; Nicholas, D.D.; Schultz, T.P. (Eds.), Wood Deterioration and Preservation. American Chemical Society Press, Washington, pp. 253-271.

DKK. 1997. Türkiye Limanlarında Fouling ve Boring Organizmalar \& Antifouling - Antiboring Boyaların Bu organizmalar Üzerine Etkinliği. DH-1049/DEBSS, 172 pp. Çubuklu, İstanbul.

Eaton, R.A. 1989. An international collaborative marine trial to in-vestigate the effect of timber substrate on the efficacy of CCA and CCB wood preservatives. Mat. u Org. 24: 51-79.

Eaton, R.A.; Hale, M.D.C. 1993. Wood: Decay, Pests and Protection. Chapman \& Hall, London.

European Committee for Standardisation. EN. 1992. Wood preservatives - Determination of the protective effectiveness against marine borers . EN 275.

Eriksen, A.M.; Gregory, D.; Shashoua, Y. 2015. Selective attack of waterlogged archaeological wood by the shipworm, Teredo navalis and its implications for in-situ preservation. Journal of Archaeological Science 55: 9-15.

Fougerousse, M. 1971. Natural resistance of tropical timbers to attack by marine wood boring organisms. In: Jones, E.B.G., Eltringham, S.K. (Eds.), Marine Borers, Fungi and Fouling Organisms. OECD, Paris, pp. 347-359.

Han, J.S.; Rowell, J.S. 1997. Chemical composition of fibers. In: Rowell, R.M.; Young, R.A.; Rowell, J.K. (Eds.), Paper and Composites from Agro based Resources. CRC Press, New York, pp. $83-134$.

Hayes, C.; Curran, P.M.T.; Hynes, M.J. 1994. Preservative leaching from softwoods submerged in Irish Coastal waters as measured by atomic-absorption spectrophotometry. Holzforschung 48: 463473.

Hill, C.A.S. 2006. Wood Modification: Chemical, Thermal and Other Processes; John Wiley: Chichester.

Hingston, J.A.; Collins, C.D.; Murphy, R.J.; Lester, J.N. 2001. Leaching of chromated copper arsenate wood preservatives: a review. Environmental Pollution 111: 53-66.

Humar, M.; Petrič, M.; Pohleven, F. 2001. Leaching of copper from wood treated with copper based wood preservatives. Drvna industrija 52 (3): 111-116.

Humar, H.; Lesar, B. 2013. Performance of Native and Copper-Ethanolamine-Treated Wood Exposed to Seawater at Port of Koper, Slovenia. Drvna Industrija 64 (4): 273-279.

Johnson, B.R. 1986. Protection of Timber Bulkheads from Marine Borers. In: Graham James, ed. Timber bulkheads. Geotech. Spec. Pub. No.7: Proceedings; Geotechnical Engineering Division of the American Society of Civil Engineers. NewYork,16-34.

King, A.J.; Cragg, S.M.; Li, Y.; Dymond, J.; Guille, M.J.; Bowles, D.J.; Bruce, N.C.; Graham, I.A.; McQueen-Mason, S.J. 2010. Molecular insight into lignocellulose digestion by a marine isopod in the absence of gut microbes. PNAS 107 (12): 5345-5350.

Lopes, D.B.; Mai, C.; Militz, H. 2014. Marine borers resistance of chemically modified portuguese wood. Madera. Ciencia y Tecnología 16 (1): 109-124.

Merkle, P.; Gallagher, D.L.; Soldberg, T.N. 1993. Leaching rates, metals distribution and chemistry of CCA treated lumber: implications for water quality monitoring. In Forest Product Society's Symposium, 'Environmental Considerations in the Use of Pressure-Treated Wood '. Forest Products 
Society, Madison, WI, pp. 69-78.

Muslich, M. 2006. The CCB Treatment of Sixteen Indonesian Wood Species Against Marine Borers. Journal of Forestry Research 30(1): 41-53.

Paalvast, P.; Van der velde, G. 2011. (Distribution, settlement, and growth of first-year individuals of the shipworm Teredo navalis L. (Bivalvia: Teredinidae) in the Port of Rotterdam area, the Netherlands. International Biodeterioration \& Biodegradation 65(3): 379-388.

Preston, A. F.; Chittenden, C. M. 1980. Marine trial progress report. Document No. IRG/WP/453. International Research Group on Wood Preservation.

Putt, A. F. 1993. Sediment bound CCA-A leachate 10 day/ repeated exposure toxicity to Ampelisca abdita under static conditions. Springborn Laboratories, Report 93-4-4730, Study 12958.1292.6100.595. Hickson Corporation Technical Center. Conley, Georgia.

Sivrikaya, H.; Cragg, S.M.; Borges, L.M.S. 2009. Variation in resistance to marine borers in commercial timbers from Turkey, as assessed by marine trial and laboratory screening. Turkish Journal of Agriculture and Forestry 33: 569-576.

Sivrikaya, H; Hafızoğlu, H; Cragg, S.M.; Carillo, A; Militz, H.; Mai, C.; Borges, L.M.S. 2012. Evaluation of wooden materials deterioreted by marine wood boring organisms in the Black Sea. Maderas. Ciencia y Tecnología 14 (1): 79-90.

Southwell, C.R.; Bultman, J.D. 1971. Marine borer resistance of untreated woods over long periods of immersion in tropical waters. Biotropica 3: 81-107.

Şen, S.; Sivrikaya, H.; Yalçın, M. 2009. Natural Durability of Some Heartwood from European and Tropical African Trees against Marine Organisms. IRG $40{ }^{\text {th }}$ Annual Meeting, Beijing, China. IRG/ WP 09-10682.

Şen, S.; Sivrikaya, H.; Yalçın, M.; Bakır, A.K.; Öztürk, B. 2010. Fouling and boring organisms that deteriorate various European and tropical woods at Turkish seas. African Journal of Biotechnology 9(17): 2566-2573.

TAPPI. 1997. Solvent extractives of wood and pulp. Test Method T $204 \mathrm{~cm}-97$.

TAPPI. 1999. Water solubility of wood and pulp. Test Method T $207 \mathrm{~cm}-99$.

TAPPI. 1993. Ash in Wood, Pulp, Paper and Paperboard, Combustion at $525^{\circ} \mathrm{C}$. Test Method T 211-om-93. TAPPI Press, Atlanta, GA.

Tascioglu, C.; Goodell, B.; Lopez-Anido, R. 2003. Bond durability characterization of preservative treated wood and E-glass/phenolic composite interfaces. Composites Science and Technology 63: 979991.

Turner, R.D. 1966. A survey and illustrated catalogue of the Teredinidae. The Museum of Comparative Zoology, Harvard University, Cambridge, M.A.

Turner, R.D. 1971. Methods d'identification des perforants et des champignons en millieu marin. In: Jones, E. B. G.; Eltringham, S. K. (eds.) Les Perforants, les Champignons et les Salissures du Bois en Millieu Marin. OECD, Paris.

Weis, P.; Weis, J.S.; Coohill, L.M. 1991. Toxicity to estuarine organisms of leachates from chromated copper arsenate treated wood. Archives of Environmental Contamination and Toxicology 20:118-124.

Westin, M.; Rapp, A.; Nilsson, T. 2006. Field test of resistance of modified wood to marine borers. Wood Material Science and Engineering 1: 34-38.

Wise, L.E.; John, E.C. 1952. Wood Chemistry. Vol. 1-2, second ed. Reinhold, New York. 